\section{Krystyna Pietrych}

Uniwersytet Łódzki

\title{
Sny (u) Szymborskiej
}

Pamięci Joli Kordackiej

\begin{abstract}
\section{Szymborska's Dreams}

The article is an attempt at an in-depth reading of one particular poem - Stuchawka (The Receiver) from the 2002 volume Chwila (A While) - by situating it in the context of Szymborska's poetic and essayistic writing. This poem has a special place among other poems of Szymborska which concern dreaming, as the dream most often occurs in her poetry as a tool for diagnosing the faults of the real world or making up for them. In The Receiver, in turn, the dream opens a space of meeting with a dead person, although, contrary to earlier thematically similar poems (Negatyw (Negative), Pamięć nareszcie (Memory at Last)), the specific character of this meeting lies in the coexistence of the dead and the living. Thus read, Szymborska turns out to be a poet of transcendence, discovering a common dimension of being which joins the reality and the dream. For her, the most important task of poetry is empathy and catharsis.
\end{abstract}

Słowa kluczowe: poezja, sen, transcendencja, empatia, katharsis

Keywords: poetry, dream, transcendence, empathy, catharsis

Szymborska nigdy nie była poetką onirycznych wizji czy zniewalających fantasmagorii. Jej wiersze, w których występuje sen, nie budują światów od jawy niezależnych, samowystarczalnie w sobie zamkniętych i kompletnych. Nie stają się także popisem wirtuozowskich mocy kreacyjnych poetki, spod której ręki wyłaniałyby się fantastyczne pejzaże, nieprawdopodobne sytuacje, 
zadziwiające metamorfozy. Nie była Szymborska nigdy wyrazicielką, wywodzącego się ze starożytności, przekonania - jak niegdyś rzecz lapidarnie ujęła Aleksandra Okopień-Sławińska - o „nadprzyrodzonym źródle inspiracji poetyckiej i sennej, opartego na podobieństwie sposobów ekspresji, a więc oddziałującego obrazowością, symbolicznością, oporem wobec objaśnień racjonalistycznych, apelowaniem do emocji, zmysłowości, intuicji i przeczuć"'. Przeciwnie - śnione światy Szymborskiej nie tyle obrazami o tajemnym pochodzeniu i znaczeniu realność zastępują, ile ją dopełniają lub w sposób paraboliczny oceniają, sytuując się najczęściej po stronie jasnego, dyskursywnego toku wypowiedzi i racjonalnego sposobu widzenia rzeczywistości, pełnego podziwu dla wielości, niezwykłości i wyją̧tkowości realnie doświadczanego, a nie innego (np. śnionego czy wyobraźniowego) świata. Punkt centralny tej poezji stanowi życie, bycie, istnienie - w ,wydaniu pierwszym”, zakorzenionym w rzeczywistości, gdzie taka różnorodność, gdzie bogactwo kształtów, zapachów, zdarzeń i przypadków wręcz nie do objęcia, bądź w „wydaniu drugim, poprawionym", otwartym na formy potencjalne, będące zarówno czystym przeczeniem, negacją bytu realnego czy możliwością, która się nie zrealizowała, jak i kreowaniem wszelkich światów prawdopodobnych, które nie zaistniały i zaistnieć by nie mogły, gdyby nie demiurgiczna moc poezji. Jeśli więc Szymborska pisze swoją żartobliwie-ironiczną Pochwatę snów

We śnie

maluję jak Vermeer van Delft.

Rozmawiam biegle po grecku

i nie tylko z żywymi.

$[\ldots]$

Jestem zdolna, piszę wielkie poematy.

$[\ldots]$

Fruwam jak się powinno, czyli sama z siebie.

Spadając z dachu umiem spaść miękko w zielone.

Nie jest mi trudno oddychać pod wodą.<smiles>C1[AlH][AlH]1</smiles>

Kilka lat temu widziałam dwa słońca.

1 A. Okopień-Sławińska, Sny i poetyka, „Teksty” 1973, nr 2, s. 7. 
A przedwczoraj pingwina.

Najzupełniej wyraźnie².

- to, aby poszerzyć rzeczywistość i zrekompensować jej mniej lub bardziej odczuwalne słabości i braki. Jak słusznie zauważył Stanisław Balbus:

Sen nie jest u Szymborskiej od jawy odgraniczony, ale wręcz stanowi jej przedłużenie i pełni wobec niej funkcje rekompensatywne; te jednak funkcje wzięte są natychmiast $\mathrm{w}$ nawias, tak, iż przedmiotem informacji utworu staje się $\mathrm{w}$ istocie nie możliwy świat snu, ale niedomogi i niedoskonałości rzeczywistości realnej³.

Sen jako narzędzie diagnozujące i/lub rekompensujące wady rzeczywistości występuje w wielu wierszach, choćby w takich, jak Obmyślam świat, Dwie małpy Bruegla, Rehabilitacja czy Pamięć nareszcie. Bez względu na to, czy tematem wiersza staje się lepsze, ,poprawione wydanie” rzeczywistości, czy rozrachunek z historią, czy też spotkanie z cudem przywróconymi do życia umarłymi, mechanizm śnienia we wszystkich powyższych przypadkach rozszerza realność o wymiary prawdopodobne i możliwe, a czasem wręcz konieczne, pożądane i niezbędne w jednostkowej perspektywie.

Nie zamierzam tu jednak układać literaturoznawczego sennika Szymborskiej i z filologiczną pedanterią oddawać się procederowi katalogowania oraz systematyzowania snów poetki ze względu na zastosowaną poetykę, literacki koncept czy pełnioną w utworze funkcję. W istocie interesuje mnie, to znaczy - niepokoi od chwili, gdy go przeczytałam, i niepokoi za każdym razem, gdy go czytam ponownie, jeden wiersz. I wszystko, co za chwilę spróbuję powiedzieć, temu jednemu doznaniu - uczuciu nieprzemijającego niepokoju towarzyszącemu każdej lekturze - jest podporządkowane i z niego wynika. Wiersz ten pochodzi z późnego tomu Chwila (2002) i nosi tytuł Stuchawka.

Najpierw jednak muszę poczynić dwie, jak sądzę niezbędne, uwagi. Pierwsza dotyczy znaczenia snów dla Szymborskiej, która nieraz w Lekturach nadobowiązkowych odnosiła się z dużym dystansem do czynionych przez psychoanalizę prób wyjaśniania snów, jak przystało na kogoś, kto nie tylko ceni umiar i rozsądek, ale kto jednocześnie odczuwa głęboki respekt wobec nieprzeniknionej tajemnicy istnienia, wiedząc, że nie da się niepoznawalnego sprowadzić do kilku wzorców mitycznych czy archetypicznych. Na marginesie książki Junga Nowoczesny mit Szymborska pisała:

Nie mogę oprzeć się wrażeniu, że z każdego snu każdy psychoanalityk wybiera sobie do interpretacji tylko te elementy, które mu są w danej chwili potrzebne. A ponieważ (o czym sama psychoanaliza nas poucza) we wszelkim wyborze bierze udział również podświadomość, należałoby i tę interpretację poddać interpretacji,

2 W. Szymborska, Wiersze zebrane, Kraków 2000, s. 190. Jeśli nie podaję inaczej, wszystkie wiersze Szymborskiej lokalizuję według tego wydania, umieszczając numer strony w nawiasie po cytacie.

3 S. Balbus, Świat ze wszystkich stron świata. O Wisławie Szymborskiej, Kraków 1996, s. 142. 
następnie i tę z kolei zinterpretować i tak dalej, i tak dalej bez końca. A może nawet bez początku, skoro wiadomo, że sen wyrażony słowami jest już czymś innym niż sen w postaci pierwotnej. Krótko mówiąc - koziołkujemy w przepaści bez dna, ale prawdopodobnie nic lepszego robić jeszcze nie umiemy ${ }^{4}$.

Istotne jest zatem dla Szymborskiej pytanie o to, co w istocie interpretujemy: cały sen czy jego fragment? Sen opowiedziany czy śniony? Konstrukt werbalny, za którym stoi cała kulturowa tradycja posługująca się wypracowaną przez wieki retoryką, topiką, symboliką, czy doświadczenie, które nam się przytrafiło w swej nagiej, przed- i pozasłownej bezpośredniości? I w swej pierwotności niewyrażalne. Jednak w psychoanalizie, ale przecież także w literaturze, mamy do czynienia jedynie ze snami wyrażonymi słowami, które zatem przestały być snami zmysłowo doznanymi. I to dopiero te dziwne pseudobyty, sny-cienie snów, poddawane są rozmaitym semantyzującym zabiegom, podporządkowanym jednemu zasadniczemu pytaniu: co ta dziwna materia bardziej mówiona niż śniona znaczy? Jednak w przytoczonej powyżej wypowiedzi, a także w kilku innych ${ }^{5}$ pojawia się coś, co Szymborską znacznie bardziej, niż sceptycznie traktowana psychoanaliza, niepokoi. Tym czymś i tu druga uwaga - jest sama materia snu, jego niezgłębiona tajemnica, coś, co sprawia, że próbując złapać niepochwytne, „koziołkujemy w przepaści bez dna". Po lekturze innej książki Junga Szymborska porównuje sposób istnienia snów po przebudzeniu do ginących pod wpływem powietrza etruskich malowideł w Rzymie Felliniego:

[...] w momencie przebudzenia rozpierzchają się i znikają bezpowrotnie. Czasem, ale też na krótko, zostaje po nich jakieś silne wrażenie. Jeszcze rzadziej się zdarza, że udaje się nam zatrzymać w pamięci któryś pojedynczy obraz, jakąś sytuację. Psychoanalitycy uznaliby, że wszystko jest w porządku - sny niepamiętane są najwidoczniej mniej ważne od zapamiętanych. Nie byłabym tego taka pewna ${ }^{6}$.

Jeszcze jedną pomijaną przez psychoanalizę kwestię podejmuje Szymborska w tym felietonie:

4 C.G. Jung, Nowoczesny mit [w:] W. Szymborska, Wszystkie lektury nadobowiazkowe, Kraków 2015, s. 621.

5 Na przykład książkę Wiktorii Dolińskiej tak Szymborska komentowała: „Dolińska dzieli sny wedle stopnia ich wewnętrznej organizacji: 1 . sny chaotyczne, których elementy nie składają się we wspólny sens, 2 . sny zawierające tylko fragmenty sensownie powiązane i 3. sny zawierające całość sensownie powiązaną. Tę trzecią grupę dzieli autorka na sny fantastyczne i sny symboliczne, przy czym tylko te ostatnie nadają się, według niej, do interpretacji. Czy jednak w takim podziale nie czai się pułapka na samego interpretatora? Łatwo może się zdarzyć, że sen, który sprawi jakąkolwiek trudność interpretacyjną, bez większych ceregieli zostanie zaszeregowany do kategorii fantastycznych lub zgoła chaotycznych...". W. Dolińska, Co mówiq nasze sny [w:] W. Szymborska, Wszystkie lektury nadobowiąkowe, s. 468.

6 W. Szymborska, Co się śni (C.G. Jung, O istocie snów) [w:] eadem, Wszystkie lektury nadobowiazkowe, s. 667. 
Opowiadając swoje sny, posługujemy się [...] jakąś składnią, która nasz tajemniczy senny chaos porządkuje i racjonalizuje, czyli przeinacza. Ścisłość relacji będzie też zależeć od zasobu słów, jakim rozporządzamy, a nawet od tradycji literackiej, jaką w sobie nosimy. Wyobraźmy sobie, że trzech panów, np. Chińczyk, Arab i Papuas, ma pewnej nocy identyczny sen. Wiem, że to niemożliwe, ale załóżmy. Ich relacje po przebudzeniu byłyby z pewnością trzema bardzo odmiennymi relacjami. Inny system językowy, inny sposób narracji, inny zasób pojęć i skojarzeń... ${ }^{7}$

Z pewnością jednak sny w swej pierwotnej postaci, w przeciwieństwie do ich werbalnych reprezentacji i psychoanalitycznych interpretacji, naprawdę fascynują Szymborską. Ich dziwny status, miejsce, z którego przychodzą, sama fenomenologia śnienia, a nade wszystko to, co z nami i w nas potrafią zrobić, stając się czasem realniejsze od jawy. Ważna z tego względu wydaje się sytuacja, o której wspomina w swojej książce Michał Rusinek:

Niełatwo było z nią poważnie rozmawiać o pisaniu, natchnieniu, inspiracji. Wszystko obracała w żart. Kiedyś i ja zażartowałem, że Miłosz miał łatwiej. Bo jemu, jak twierdził, daimonion szeptał wiersze do ucha. Pani Wisława - o dziwo - spoważniała i powiedziała: „Wie pan, ale ja także słyszę głosy. Mnie się śnią słowa, zdania"s.

To, co przynosi sen, niespodziewanie u poetki, która, jak się sama określiła, ,woli czas owadzi od gwiezdnego”, okazuje się niezwykle ważne i poważne, nie bez powodu wszak w tym samym wierszu dodawała: „wolę brać pod uwagę nawet tę możliwość, / że byt ma swoją rację" (Możliwości). Dlatego - i tu wracam do tytułu mojego wystąpienia - będę próbowała mówić o snach (u) Szymborskiej, biorąc to „u” w nawias. Co nie jest ani wyrazem nonszalanckiej gry językowej, ani potrzebą schlebiania dość powszechnej modzie, ale wynika ze sposobu potraktowania owego w nawiasie ,u” jako znaku pomiędzy doświadczeniem poetki a nadanym mu poetyckim kształtem. Wiersze, które będę tu przywoływać, mają swe źródło - takie mam głębokie poczucie w przestrzeni osobistego doświadczenia. Potwierdza to korespondencja poetki z Kornelem Filipowiczem, który często pisze o swoich snach związanych z osobą adresatki listów. Szymborska rewanżuje się tym samym:

\section{Ibidem.}

8 M. Rusinek, Nic zwyczajnego. O Wisławie Szymborskiej, Kraków 2016, s. 121. Jak powiedziała zaprzyjaźniona z Szymborską Urszula Kozioł: „Wisława, wielka racjonalistka, z dużą nieufnością odnosiła się do wszelkich irracjonalizmów. Jeśli chodzi o pisanie wierszy, obstawała jednak przy tajemnicy. Uważała, że tworzenie to sekret, zagadka". A. Bikont, J. Szczęsna, Pamiątkowe rupiecie. Biografia Wisławy Szymborskiej, Kraków 2012, s. 186-187. 
Moje sny też są miłe, np. że byliśmy razem w cyrku, że nagle zniknąłeś, a ja bałam się, że poleciałeś za kulisy do dzikich zwierząt, a później znów siedziałeś przy mnie i jedliśmy lody Bambino9.

W związku zaś z wierszem Stuchawka warto przywołać jeszcze jeden ważny kontekst biograficzny - wieloletni zwyczaj codziennych telefonów. „Ale zawsze o dziewiątej rano wydaje mi się, że powinien zadzwonić telefon"10 - stwierdza Szymborska, a Filipowicz kilka lat później pisze niemal to samo: „Brakuje mi już trochę porannych telefonów od Ciebie”"1. Aktywizowana listami, wywiadami czy wspomnieniami, ale także niektórymi wierszami prywatna przestrzeń inicjuje szczególny sposób czytania, sytuujący się pomiędzy snami Szymborskiej a snami zapisanymi w jej poezji. Bez rozstrzygnięcia.

I teraz powracam do wiersza Stuchawka.

Śni mi się, że się budzę,

bo słyszę telefon.

Śni mi się pewność, że dzwoni do mnie umarły.

Śni mi się, że wyciągam rękę po słuchawkę.

Tylko ta słuchawka nie taka jak była, stała się ciężka, jakby do czegoś przywarła, w coś wrosła, coś oplotła korzeniami. Musiałabym ją wyrwać razem $\mathrm{z}$ całą Ziemią.

Śni mi się mocowanie moje nadaremne.

Śni mi się cisza, bo zamilknął dzwonek.

Śni mi się, że zasypiam

i budzę się znów ${ }^{12}$.

W tomie Koniec i poczatek Szymborska pisała: „Jawa nie pierzcha / jak pierzchają sny" (Jawa). W wierszu Stuchawka sny jednak nie pierzchają, sta-

9 W. Szymborska, K. Filipowicz, Listy. „Najlepiej w życiu ma Twój kot”, Kraków 2016, s. 138.

10 Ibidem, s. 198.

11 Ibidem, s. 298.

12 W. Szymborska, Chwila, Kraków 2002, s. 13. 
nowiąc wraz z jawą jakąś zapętloną jedność, niedającą się podzielić na dwa odrębne wymiary. Sen trwa bez końca, jawa trwa bez końca, sen-jawa trwa bez końca... Aby nieco więcej móc o tej jedności powiedzieć, muszę przywołać kilka istotnych kontekstów.

Po pierwsze, kontekst tomu Chwila. W porządku następowania po sobie tekstów Stuchawke poprzedza wiersz opisujący negatyw zdjęcia, na którym widać twarz bliskiego zmarłego. Zgodnie z zastosowaną w tym utworze zasadą odwróconego w stosunku do ziemskiej rzeczywistości porządku, która ma oddawać ciemność zaświatów, sama technika fotograficzna (negatyw) staje się swoistym wehikułem umożliwiającym ponowne zaistnienie tego, kto w inny sposób pojawić się już nie może:

Na twojej ciemnej twarzy jasne cienie.

Zasiadłeś przy stoliku

i położyłeś na nim poszarzałe ręce.

Sprawiasz wrażenie ducha, który próbuje wywoływać żywych ${ }^{13}$.

Jak rzecz ujął trafnie Wojciech Ligęza: „Strona śmierci zyskuje kształt odwróconego życia”. I kontynuował:

W krainie zmarłych świeci czarne słońce, o czym można się przekonać, patrząc na negatyw fotografii. Zatem czarny pejzaż ulega obiektywizacji. To, co niedocieczone i nieznane, posiada alibi empirii. Przejmująca elegia - Negatyw Wisławy Szymborskiej - na pewno należy do kategorii „wierszy przecierpianych”14.

Takiego określenia użyła Szymborska w rozmowie z Teresą Walas i jednocześnie z charakterystyczną dla siebie dyskrecją zastrzegła: „nie będziemy tu o tym mówić” ${ }^{15}$. Z pewnością wierszem ,przecierpianym” jest także Stuchawka, tworząca wraz z Negatywem żałobny dyptyk, który jednak bólu rozstania poetyckim konceptem ani nie przesłania, ani nie łagodzi, lecz przeciwnie - sprawia, że to rozstanie staje się dojmująco aktualne i bolesne. „Alibi empirii" "16 nie stanowi tu dowodu na życie po tej drugiej stronie, zadaje raczej kolejny bolesny cios temu, kto, będąc po tej stronie, wpatruje się w negatyw i potem (przynajmniej w linearnym porządku tomu - kolejność wierszy sugerować tu może także następstwo sytuacyjne) próbuje bezskutecznie odebrać telefon.

13 Tamże, s. 12.

14 W. Ligęza, O poezji Wisławy Szymborskiej: świat w stanie korekty, Kraków 2001, s. 275.

15 Lekcja zdziwienia światem (pierwszy wywiad telewizyjny z Wisławą Szymborską przeprowadzony przez Teresę Walas w dniu przyznania Poetce Nagrody Nobla) [w:] Radość czytania Szymborskiej. Wybór szkiców krytycznych, oprac. S. Balbus, D. Wojda, Kraków 1996, s. 21.

16 W. Ligęza, op.cit., s. 275. 
Fotografia już niegdyś stała się w poezji Szymborskiej wehikułem pamięci, otwierając we śnie przestrzeń niemożliwego w inny sposób spotkania. W wierszu Sen, z tomu Sól, apostrofa do bliskiego zmarłego ,z cieniem liścia na twarzy" wydaje się jakby wcześniejszym wariantem wiersza Negatyw. Gdy czytamy:

Mój poległy, mój w proch obrócony, mój ziemia, przybrawszy postać, jaką ma na fotografii:

$\mathrm{z}$ cieniem liścia na twarzy, z muszlą morską w ręce, wyrusza do mojego snu (s. 100).

możemy odnieść wrażenie, że to bogatsza, bo w większym stopniu wypełniona szczegółami sytuacja spotkania, do jakiego dochodzi „na wewnętrznej stronie moich powiek". Wtedy ten, który ma „serce przestrzelone”, może przekroczyć granicę zdjęcia i przeniknąc do snu swej ukochanej ${ }^{17}$. Ów bliski poetce chłopak ma w wierszu aktywną moc, uruchamianą siłą kreacyjnej poetyckiej wyobraźni, choć w jakiejś mierze także od niej niezależną. Zwracał na to uwagę przed laty Artur Sandauer:

Już samo początkowe „wyrusza do snu” wywraca ontologię na nice. Powiedzieć, że wyrusza, to przypisać mu cień niezależności; użyć przyimka „do”, to uczynić ze snu - gotową przed jego przyjściem scenę. Zaś wyruszać można tylko do celu, który przed wybraniem się w podróż istnieje, więc ów sen wykracza poza własne czasowe granice, zaczyna się - przed samym sobą. Bo też rzeczywiście zaczął się, nim się zaczął: jest spełnieniem wieloletnich oczekiwań, bezcielesne dotąd wspomnienie się ucieleśnia. Ale jeżeli poległy zjawia się, to tylko na modłę negatywną. Sen o nim jest prześwietlony samowiedzą: wie, że śni się, i wie, że to, o czym śni, nie istnieje ${ }^{18}$.

Trudno do końca zgodzić się z Sandauerem w ostatniej kwestii: nie wydaje się, aby powołany do istnienia świat został ostatecznie zakwestionowany. Przeciwnie, pomimo zaznaczonej w wierszu świadomości śnienia, następuje niebywale silna sensualna konkretyzacja, wieloma szczegółami wypełniona reaktywacja przestrzeni, w której ponownie mogą się spotkać kochankowie:

Zaczyna istnieć łąka między nami, nadlatują niebiosa $\mathrm{z}$ chmurami i ptactwem, na horyzoncie cicho wybuchają góry

i rzeka spływa w dół w poszukiwaniu morza.

17 „Gdzieś napomknęła Szymborska, że chłopak, w którym kochała się na początku wojny, zmarł tragicznie w obozie w Prokocimiu, gdzie indziej, że w Powstaniu Warszawskim zginął jej kuzyn Roman Lenkiewicz, syn ciotki Julii. Nam opowiadała o ukochanym, którego AK wysłało z misją do Wilna: - To był 1943, może 44 rok. A potem żaden list nie przychodził. Dowiadywałam się, szukałam, ale nie natrafiłam nigdy na żaden ślad". A. Bikont, J. Szczęsna, op.cit., Kraków 2012, s. 71.

18 A. Sandauer, Pogodzona z historia [w:] Radość czytania..., s. 63. 
Już tak daleko widać, tak daleko,

że dzień i noc stają się równoczesne,

a wszystkie pory roku zaznawane naraz.

Księżyc czterokwadrowy wachlarz rozpościera, wirują płatki śniegu razem z motylami

i z kwitnącego drzewa spadają owoce (s. 100).

„Teraz” łączy w sobie wymiary dotąd przeciwne: dzień i noc, wszystkie pory roku, czas kwitnienia i czas owocowania, życie i śmierć ${ }^{19}$. Ta jednoczesność zadaje się pełnią - niegdyś utraconą, w poetyckim śnie na nowo odzyskaną siłą lirycznego zaklęcia. Może więc w końcu dojść do zaślubin zmarłego z „przestrzelonym sercem” i żyjącej, pogrążonej we śnie. Sugestywność tego obrazu przesłania negatywną modalność tekstu - nieżyjący materializuje się mimo wszystko w wyobraźni, jakby we śnie z prochu powstając. Podobnie w wierszu Pamięć nareszcie (tom Sto pociech), gdy zjawiali się w końcu zmarli rodzice:

No i nareszcie.

Pewnej zwykłej nocy,

z pospolitego piątku na sobotę,

tacy mi nagle przybyli, jakich chciałam (s. 115).

Jak rzecz trafnie widział Jacek Łukasiewicz: „Rodzice po czyśćcu przebywania w dziwacznych, groteskowych snach córki osiągają niebo rembrandtowskiego portretu" ${ }^{20}$. W finale wiersza Sen niemalże słychać ,nasz weselny marsz”, w zakończeniu Pamięć nareszcie rodzice „zdawali mi się długo, długo i szczęśliwie". Oba utwory poświadczają kompensacyjną siłę oddziaływania snu, który niczym baśń (lub dzieło sztuki) może przemienić poczucie utraty w jakiś rodzaj spełnienia, dostępnego w innym niż jawa wymiarze. Co oczywiście nie znaczy, że wizja śniona po prostu zastępuje realność, przebudzenie wszak kiedyś nastąpi. Ale, i to jest samo w sobie niezwykle cenne, śniona wizja czyni realność nieco bardziej znośną, choćby przez chwilę.

W wierszu Stuchawka sytuacja w pierwszym momencie może wydawać się podobna, bo tekst także opowiada o spotkaniu z umarłym; spotkaniu, do którego jednak nie dochodzi. Czy jednak na pewno? Niegdyś na marginesie lektury pamiętnika Marie-Jeanne Roland, pisanego w czasie rewolucji francuskiej, gdy diarystka oczekiwała na szafot, Szymborska wskazała jakby mimochodem ważny trop lektury własnych wierszy:

[...] pamiętnik obiecuje nam wzruszenie o spóźnionym, ale przedłużonym działaniu. Jest przecież obrazem codziennej zwycięskiej walki, jaką toczyć musiała autorka $\mathrm{z}$ własną słabością, udrękami więziennymi i lękiem śmiertelnym. Nie to

19 Za tę sugestię interpretacyjną dziękuję prof. Teresie Walas.

20 W. Ligęza, op.cit., s. 203. 
w nim najważniejsze, co wyraziły słowa, ale to, czego nie wyraziły. Czego autorka surowo sobie zabroniła, aby trzymać się prosto aż do końca ${ }^{21}$.

Traktując powyższe słowa jako zakamuflowany autokomentarz, warto podjąć próbę dotarcia do tego, czego „słowa [wprost] nie wyraziły” w wierszu Stuchawka.

Pierwsze trzy dystychy, rozpoczynające się uparcie powracającą anaforą, kreślą niemal codzienną sytuację, w której ktoś relacjonuje swój sen. Niepokoi co prawda użyty czas teraźniejszy zamiast przeszłego (częściej opowiadamy, mówiąc „,śniło mi się”), jednak owo powtarzane uporczywie „śni mi się” spełnia ważną rolę: sugestywnie osadza nas w aktualności dziania się, znosząc jakikolwiek dystans wobec przedstawianych wydarzeńn ${ }^{22}$. Wszystko zatem dzieje się „teraz” i z tego ”teraz” niepodobna się wydostać. Przypomnijmy:

Śni mi się, że się budzę,

bo słyszę telefon.

Śni mi się pewność,

że dzwoni do mnie umarly.

Śni mi się, że wyciągam rękę

po słuchawkę̨.

Ta sytuacja przecież przyśnić się może, można też we śnie doświadczyć niepojętej dla trzeźwej jawy pewności, że „dzwoni umarły”. Jak powiedziała Szymborska autorkom swej biografii: „W tym wierszu nie ma nic wymyślonego [...]. To był prawdziwy, autentyczny sen. I naprawdę wiedziałam, kto dzwoni" 24 .

Środkowa część wiersza do pewnego momentu, także jak na śnioną rzeczywistość, wydaje się prawdopodobna i niemal każdemu dostępna - niemożność podniesienia słuchawki to szczególna wersja labiryntowego błądzenia, kiedy to już, niemal za chwilę, mamy gdzieś trafić, a tu raptem droga skręca niespodziewanie w lewo lub nie wiedzieć czemu dochodzimy nie tam, dokąd zmierzaliśmy. Takie sny zdarzają się chyba od czasu do czasu każdemu. Jednak w wierszu Szymborskiej ta uniwersalna sytuacja została przyobleczona w materialny konkret - uroślinniona słuchawka „w coś wrosła, coś oplotła korzeniami”. Wyobraźnia podsuwa nam teraz obraz niczym z surrealistycznego horroru: ukorzenionej słuchawki, oplatającej swymi podziemnymi rozgałęzie-

${ }^{21}$ Marie-Jeanne Roland, Pamiętniki [w:] W. Szymborska, Wszystkie lektury nadobowiązkowe, s. 472.

22 Owo „śni mi się" można też odnosić do sytuacji wielokrotnie się powtarzającej. Za tę wskazówkę dziękuję prof. Stanisławowi Balbusowi.

23 W. Szymborska, Chwila ..., s. 13.

24 A. Bikont, J. Szczęsna, op.cit., s. 247. 
niami czy (jak to nazwać?) odnogami grób ${ }^{25}$. Aby ją podnieść, trzeba by ,ją wyrwać razem z całą Ziemią". A zatem to sen-koszmar?

Warto zauważyć, że przywoływany wiersz Sen otwiera zwrot: „Mój poległy, mój w proch obrócony, mój ziemia". Niepokoi mnie to ostatnie imię zmarłego - nieoczywiste i stanowiące rodzaj gramatycznego zaburzenia, które, jak sądzę, ma na celu u poetki, posługującej się zazwyczaj tokiem racjonalnie zdyskursywizowanym, na coś istotnego skierować naszą uwagę. Imię „mój ziemia” wskazuje na miejsce jego aktualnego przebywania, to stamtąd wyrusza do snu ukochanej. Telluryczne jest miejsce wspólnego dla wszystkich ostatecznego spoczynku. Takie znaczenie także aktywizuje się w wierszu Stuchawka, ale już po chwili wypiera je semantyka Ziemi (pisanej wielką literą) - a więc całego globu, a może nawet całego bytu.

Środkowa część Stuchawki stanowi także wyrazisty kontrapunkt w stosunku do owej sensualnej pełni, jednoczącej wartości opozycyjne w wierszu Sen. Tam ów sytuujący się na granicy żywych i umarłych świat wyposażony został w sugestywną siłę oddziaływania, aktywowaną przede wszystkim zmysłem wzroku. Kolejno wyłaniające się obrazy stworzyły harmonijną całość, opartą na coincidentia oppositorum. W wierszu z tomu Chwila wrażenia wzrokowe nie dominują, choć nadal pozostają wyjątkowo sugestywne. Jednak rolę pierwszoplanową przejmują przeciwstawne doznania akustyczne, kontrapunktowo-dysonansowe, dźwięk telefonu i cisza, które nigdy nie zleją się w brzmieniową jedność.

I trzy dystychy zamykające wiersz, niepokojąco zwierciadlane w stosunku do początkowych. Dwa budują sytuację uporczywego, pozbawionego końca mocowania się ze słuchawką i głuchej ciszy zapadającej po milknącym dzwonku. Wrażenie bezcelowości i jałowości podejmowanych wysiłków intensyfikuje wyodrębnione osobnym wersem słowo „daremnie”, a inicjalny dźwięk telefonu wymiennie z finalną ciszą buduje sytuację szczelnego uwięzienia. Trzeci i ostatni wers na zawsze umieszcza nas we wnętrzu, z którego nie sposób się wydostać:

Śni mi się, że zasypiam

i budzę się znów ${ }^{26}$.

Jawa to czy sen? Rozstrzygnąć niepodobna. W wierszu Stuchawka jest niczym w często przytaczanym powiedzeniu Czuang-tsy, który śnił, że jest motylem, a po przebudzeniu zastanawiał się, czy aby nie jest motylem śniącym, że jest człowiekiem ${ }^{27}$. Nie ma tylko retorycznej motylej zwiewności, bo

25 Na temat surrealistycznej wyobraźni Szymborskiej zob. choćby M. Baranowska, „Tak lekko byłoby nic o tym nie wiedzieć”. Szymborska i świat, Wrocław 1996, s. 79-81; W. Ligęza, Wspominać z wdzięcznościa [w:] Zachwyt i rozpacz. Wspomnienia o Wistawie Szymborskiej, wybór, red. i oprac. A. Papieska, Warszawa 2014, s. 259-260.

26 W. Szymborska, Chwila ..., s. 13.

27 Zob. Czuang-tsy, O wyrównywaniu przeciwieństw [w:] Antologia literatury chińskiej, przeł. J. Chmielewski, A. Dębicki i in., Warszawa 1956, s. 58-59. 
rzeczywistość wiersza groźnie i klaustrofobicznie nas osacza. Tę sytuację hermetycznego zamknięcia oddaje także budowa stroficzna, zamykająca klamrowo usytuowanymi trzema dystychami przestrzeń wiersza - jakby na zawsze i ostatecznie. (Nota bene nie znam drugiego wiersza Szymborskiej o takiej budowie stroficznej.)

Niemożność oddzielenia jawy od snu ma zasadnicze znaczenie. Wydaje mi się, że różne sposoby istnienia czy, jak mówią filozofowie, odmienne statusy ontologiczne, zostają zniesione, bo okazują się tożsame. Podobnie jak w wierszu Niebo, w którym ,podział na ziemię i niebo uważa poetka za ułomny, nieoddający całości będącej ich połączeniem" ${ }^{28}$. W istocie to przecież niepodzielna całość, jeden byt, który zwykliśmy z braku subtelniejszych narzędzi poznania oraz adekwatniejszych określeń nazywać ziemią i niebem, jawą i snem. Przecząc temu, co istnieje w sposób nieakcydentalny, ale nie ośmieliłabym się po prostu powiedzieć, że esencjalny. Stanisław Balbus, komentując wiersz Niebo, nazwał ową całość „uniwersum światów możliwych”29 - Kosmosem i Wszechświatem:

Zbudowanym z tej samej materii i energii, co każdy z nas i cała nasza planeta; z materii i energii, która nas na wskroś przenika, wypełnia i w której jako całości wszechświata jesteśmy zanurzeni - zawsze i na zawsze, boć również i po śmierci, po rozpadzie ciała na atomy ${ }^{30}$.

Stan ni to jawy, ni to snu - choć lepiej powiedzieć: jawy i snu zjednoczonych - jest też jednym stanem, tworzącym wspólnotę żywych i umarłych. Otwiera się tutaj jakaś przestrzeń metafizyczna, choć Szymborska tak by nigdy jej nie nazwała, wzbraniając się przed wmówieniem, uzurpacją, ,pychą poznawczą" "31. Taka postawa jest w swych rudymentach religijna, w sposób, o jakim we wspomnieniu o Szymborskiej mówił Ireneusz Kania, wskazując wątki buddyjskie obecne w jej twórczości:

Wisława nie przylegała wewnętrznie do żadnej instytucjonalnej religii, [...] była fundamentalnie agnostycka, natomiast jej religijność można by zdefiniować [...] jako wyczucie transcendencji rzeczywistości, jako przeświadczenie, że nasze wysiłki, słowa czy idee są absolutnie niewspółmierne do tego, co czujemy, że istnieje coś, w czym wszystko jest zanurzone, a czego w żaden sposób nie potrafimy uchwycićs ${ }^{32}$.

28 M. Baranowska, op.cit., s. 108.

29 S. Balbus, op.cit., s. 175.

30 Ibidem.

31 Zob. ibidem, s. 172-173.

32 I. Kania, Wchodzimy w tajemnice jak w katuże (rozmawia A. Papieska) [w:] Zachwyt i rozpacz. Wspomnienia o Wisławie Szymborskiej, s. 149. Sama Szymborska twierdziła, że „wiara nie musi być ujęta w dogmat. Nikt nie jest całkowicie niewierzący”. A. Bikont, J. Szczęsna, op.cit., s. 58. 
„W żaden sposób” - chyba że na chwilę w wierszu błyśnie tajemnica, otaczająca nas ze wszystkich stron. Tylko poezja może ten nikły błysk pochwycić i na chwilę zatrzymać. Tylko w poezji, według Szymborskiej, czasem otwiera się możliwość oddania grozy i fascynacji istnieniem, co jest literalnie zgodne z klasyczną definicją religijności Rudolfa Otto (misterium tremendum et fascinans $)^{33}$. Poza przestrzenią poezji pozostaje milczenie:

[...] ważnym składnikiem jej - kontynuuje Kania - religijności jest postrzeganie świata jako tajemnicy dla nas niedostępnej, choć otaczającej nas ze wszystkich stron; tajemnicy, w którą wdeptujemy jak w kałużę - o tej kałuży zresztą pisała, to jedna $\mathrm{z}$ figur jej światopoglądu - milczenia wobec tajemnicy ${ }^{34}$.

W Stuchawce, podobnie jak we wspomnianym powyżej wierszu Kałuża, udało się Szymborskiej nieco nadwątlić to milczenie słowem, które dotyka grozy istnienia. I jednocześnie zasugerować zdumiewającą jedność bytu. Poetka - o której Miłosz powiedział, że „ofiarowuje nam świat, w którym można oddychać" 35 - przesłoniła tę grozę swą sygnaturą: tym razem nie ironii, lecz dyskrecji i powściągliwości, aby nikogo śmiertelnie nie przerazić. Jej, jak to kiedyś ujęła Małgorzata Baranowska, ,zdolność patrzenia prawdzie w oczy"36, zrównoważona została darem wielkodusznego współczucia. Bo lepiej czasem pewne rzeczy zataić i nie do końca wiedzieć, „na jakim świecie się żyje" ${ }^{37}$. W ten sposób mocą poetyckiej transformacji śniony koszmar zyskał w jakiejś mierze działanie katartyczne, które nie uwalnia co prawda od cierpienia, ale pozwala nie poddać się rozpaczy i zaakceptować wspólny nam wszystkim $\operatorname{los}^{38}$.

33 Zob. I. Kania, op.cit., s. 150.

34 Ibidem.

35 Cz. Miłosz, Poezja jako świadomość [w:] Radość czytania ..., s. 34.

6 M. Baranowska, op.cit., s. 106.

37 „Wielkie to szczęście / nie wiedzieć dokładnie, / na jakim świecie się żyje” pisała Szymborska w wierszu, którego tytuł stanowi pierwszy wers (tom Koniec i poczatek).

$38 \mathrm{~W}$ rozmowie zamieszczonej w tomie wspomnień o Szymborskiej Stanisław Balbus powiedział: „Arystoteles, chcąc wydobyć humanistyczny sens greckiej tragedii, wymyślił termin katharsis: po poznaniu uczuć litości i trwogi następuje oczyszczenie. Patheia po grecku to raczej współodczuwanie niż litość w naszym potocznym rozumieniu: rozpoznanie w sobie drugiego. Powiedziałbym zatem, że nie „ocalenie” niesie poezja Szymborskiej, lecz katharsis. Przeżywszy bóle i radości świata, zyskujemy nową mądrość, jaśniejsze widzenie swojego losu, nawet śmierć przestaje być straszna”. S. Balbus (rozmawia A. Papieska), Tyle śmierci, ile życia [w:] Zachwyt i rozpacz. Wspomnienia o Wisławie Szymborskiej, s. 21. 


\section{Bibliografia}

Balbus S., Świat ze wszystkich stron świata. O Wisławie Szymborskiej, Kraków 1996.

Baranowska M., ,,Tak lekko byłoby nic o tym nie wiedzieć”. Szymborska i świat, Wrocław 1996.

Bikont A., Szczęsna J., Pamiątkowe rupiecie. Biografia Wisławy Szymborskiej, Kraków 2012.

Czuang-tsy, O wyrównywaniu przeciwieństw [w:] Antologia literatury chińskiej, przeł. J. Chmielewski, A. Dębicki i in., Warszawa 1956, s. 58-59.

Ligęza W., O poezji Wisławy Szymborskiej: świat w stanie korekty, Kraków 2001.

Okopień-Sławińska A., Sny i poetyka, „Teksty” 1973, nr 2.

Radość czytania Szymborskiej. Wybór szkiców krytycznych, oprac. S. Balbus, D. Wojda, Kraków 1996.

Rusinek M., Nic zwyczajnego. O Wisławie Szymborskiej, Kraków 2016.

Szymborska W., Wszystkie lektury nadobowiązowe, Kraków 2015.

Szymborska W., Filipowicz K., Listy. „, Najlepiej w życiu ma Twój kot”, Kraków 2016.

Zachwyt i rozpacz. Wspomnienia o Wistawie Szymborskiej, wybór, red. i oprac.

A. Papieska, Warszawa 2014. 